bioRxiv preprint doi: https://doi.org/10.1101/2021.08.15.456243; this version posted August

15,2021 . The copyright holder for this preprint (which was not certified by peer review) is the author/funder. All rights reserved. No reuse allowed without permission.

\title{
A nanopore ion source delivers single amino acid and peptide ions directly into the gas phase
}

\author{
Nicholas Drachman ${ }^{1}$, Mathilde LePoitevin ${ }^{1}$, Hannah \\ Szapary ${ }^{1}$, Benjamin Wiener ${ }^{1}$, William Maulbetsch ${ }^{1}$ and Derek \\ Stein $^{1,2}$ \\ ${ }^{1}$ Physics Department, Brown University, 182 Hope street, Providence, \\ 02906, RI, USA. \\ ${ }^{2}$ School of Engineering, Brown University, 184 Hope street, Providence, \\ 02906, RI, USA.
}

\begin{abstract}
A technology for sequencing single proteins would expand our understanding of biology and improve the detection and treatment of disease [1]. Approaches based on fluorosequencing [2], nanopores [3, 4], and tunneling spectroscopy [5] are under development and show promise. However, only mass spectrometry (MS) has demonstrated an ability to identify amino acids with minimal degeneracy [6]. We envision sequencing a protein by fragmenting it and delivering its constituent amino acids into a mass spectrometer in sequential order, but existing ion sources employ a background gas that scrambles the spatial ordering of ions and degrades their transmission. Here we report an ion source comprising a glass capillary with a sub-100 $\mathrm{nm}$ diameter pore that emits amino acid ions from aqueous solution directly into vacuum. Emitted ions travel collision-less trajectories before striking a single-ion detector. We measured unsolvated ions of 16 different amino acids as well as glutathione and two of its post-translationally modified variants.
\end{abstract}

Keywords: protein sequencing, nanopore, mass spectrometry, single molecule 
bioRxiv preprint doi: https://doi.org/10.1101/2021.08.15.456243; this version posted August 15,2021 . The copyright holder for this preprint (which was not certified by peer review) is the author/funder. All rights reserved. No reuse allowed without permission.

Mass spectrometry is the workhorse of proteomics research thanks to its ability to distinguish amino acids by their mass [6]. Its utility also significantly derives from the availability of soft ionization techniques for transferring peptide ions into the vapor phase intact [7]. In particular, electropray ionization (ESI) transfers analyte into a mass spectrometer via a plume of charged droplets that emerge from a liquid cone-jet at the end of a voltage-biased capillary, as illustrated in Fig. 1a [8]. The droplets pass through an atmospheric-pressure background gas that induces a string of evaporation and Coulomb explosion cycles that ultimately release analyte ions into the gas phase for analysis [9]. The ESI process presents two fundamental challenges for single-protein analysis and sequencing: First, collisions with the background gas molecules quickly scramble the spatial ordering of amino acid ions, which must be preserved for sequencing [10]. Second, only a fraction of the analyte molecules passing through an electrospray source are actually measured, because many molecules never emerge from droplets as ions [9], and many of the ions that do emerge are lost to collisions with components of the mass spectrometer, especially the transfer capillary that bridges the atmospheric-pressure ion source and the high-vacuum region of the mass spectrometer $[11,12]$. The low ion transfer efficiency of ESI sources significantly affects the sensitivity of MS, and millions to billions of copies of a protein are typically required for its identification [12].

We have developed a nanopore ion source that emits amino acid ions directly into high vacuum (Fig. 1b). The heart of the ion source is a pulled quartz capillary whose tip inner diameter is smaller than $100 \mathrm{~nm}$. We reasoned that the smallness of the tip will influence ion emission in three important ways: First, the fluid flow rate, which scales as the inverse cube of the tip diameter, will be far too low for a stable cone-jet to form [13, 14], and this might prevent charged droplets from being emitted. Second, the surface tension of a 
bioRxiv preprint doi: https://doi.org/10.1101/2021.08.15.456243; this version posted August 15,2021 . The copyright holder for this preprint (which was not certified by peer review) is the author/funder. All rights reserved. No reuse allowed without permission.

water meniscus can support many atmospheres of pressure and maintain a stable liquid-vacuum interface when stretched across a nanoscale opening. Third, electric fields concentrate at a sharp, conductive tip like an electrolyte-filled nanocapillary, so it might be possible to achieve electric fields of $\sim 1 \mathrm{~V} / \mathrm{nm}$ at the liquid meniscus [15]. At that high field strength, ions can escape from a liquid at high rates by the process of ion evaporation [16].

Figure 1c shows an overview of our custom mass spectrometer [17]. Ions are emitted from the source by applying a voltage between a $\mathrm{Ag} / \mathrm{AgCl}$ electrode inside the nanocapillary and a ring-shaped extraction electrode located about $5 \mathrm{~mm}$ in front of the nanopore tip. The ions pass through focusing ion optics, a quadrupole mass filter and an ion bender (Extrel CMS) before being measured by a continuous dynode single-ion detector (DeTech). [17]. The background pressure inside the instrument is typically $10^{-7}$ torr, and the mean free path of an amino acid $(>100 \mathrm{~m})$ is orders of magnitude larger than the size of the instrument.

We prepared aqueous solutions of 16 different amino acids at concentrations of $100 \mathrm{mM}$, with the exception of tryptophan, which was prepared at $50 \mathrm{mM}$ concentration due to its low solubility. To generate positive amino acid ions, we lowered the $\mathrm{pH}$ of each solution below the relevant isoelectric point by the addition of acetic acid. We pre-filled a nanocapillary with an amino acid solution before inserting it into the vacuum chamber as described previously [17]. An extraction voltage $V_{e}$ in the range $+260 \mathrm{~V}$ to $+360 \mathrm{~V}$ applied between the nanocapillary and the extraction electrode initiated the emission of an ionic current of several picoamperes. The onset of emission was typically abrupt and accompanied by the measurement of ions striking the instrument's detector at a rate sufficient for interpretable mass spectra to be collected within minutes. 
bioRxiv preprint doi: https://doi.org/10.1101/2021.08.15.456243; this version posted August 15,2021 . The copyright holder for this preprint (which was not certified by peer review) is the author/funder. All rights reserved. No reuse allowed without permission.

Fig. 1d shows the mass spectrum of an arginine solution obtained using a nanopore ion source with inner tip diameter of $41 \mathrm{~nm}$. Five peaks are clearly visible. The peak at $175 \mathrm{~m} / z$ corresponds to the singly charged arginine ion $\left(\mathrm{Arg}^{+}\right)$. The higher $\mathrm{m} / z$ peaks are all separated by $18 \mathrm{~m} / z$, the shift induced by an additional water molecule. Thus, the other peaks correspond to solvated states of arginine $\left(\mathrm{Arg}^{+}\left(\mathrm{H}_{2} \mathrm{O}\right)_{n}\right)$, where the solvation number $n$ ranges from 1 to 4 .

Figure 2a illustrates how the tip diameter influences arginine mass spectra. The spectra shown were obtained using nanocapillaries with inner tip diameters of $20 \mathrm{~nm}, 125 \mathrm{~nm}$, and $300 \mathrm{~nm}$. The largest nanotip produced a broad spectrum of peaks that includes the bare arginine ion, eight incrementally hydrated arginine ion clusters, and a peak at $349 \mathrm{~m} / \mathrm{z}$ that corresponds to the arginine dimer ion $(\mathrm{Arg} \cdot \mathrm{Arg}+\mathrm{H})^{+}$. The intermediate-sized tip produced a narrower spectrum that includes the bare arginine ion, six incrementally hydrated arginine ion clusters, and a relatively diminished arginine dimer ion peak. The smallest tip primarily produced the bare arginine ion, but attenuated peaks corresponding to the singly and doubly hydrated arginine ion clusters are also visible in the spectrum. Smaller tips tended to produce relatively stronger signals and less noisy spectra than larger tips, as can be seen by comparing the baselines of the three spectra in Fig. 2a. We observed some variance in the distribution of solvation states between nanocapillaries with similar tip sizes (e.g., compare the spectrum in Fig. 1d produced by a $20 \mathrm{~nm}$ tip to the spectrum from Fig. 2a produced by a $41 \mathrm{~nm}$ tip). However, only nanocapillaries with inner tip diameters smaller than about $65 \mathrm{~nm}$ produced spectra where most of the amino acid ions were measured in the unsolvated state. 
bioRxiv preprint doi: https://doi.org/10.1101/2021.08.15.456243; this version posted August 15,2021 . The copyright holder for this preprint (which was not certified by peer review) is the author/funder. All rights reserved. No reuse allowed without permission.

The nanopore ion source generates ions of diverse amino acids and small peptides for analysis. We routinely swapped solutions inside the nanocapillary without interrupting the measurement using a previously described fluid delivery system [17]. Figure 2b shows mass spectra obtained from 16 different aqueous amino acid solutions. Four different nanopocapillaries with inner tip diameters of 20, 25, 57 and $58 \mathrm{~nm}$ were used for these measurements. The most prominent amino acid peak in every spectrum shown in Fig. 2b corresponds to a singly charged and unsolvated ion. The spectra for glycine, alanine, proline, valine, cysteine, glutamine, and phenylalanine show no additional peaks which could correspond to solvated amino acid ions. The spectra for serine, threonine, asparagine, lysine, methionine, histidine, arginine, and tryptophan show a secondary peak $18 \mathrm{~m} / \mathrm{z}$ to the right of the unsolvated peak, corresponding to the singly hydrated amino acid ion. Leucine shows a third and possibly fourth peak corresponding to higher solvation states. The tryptophan spectrum shows peaks below $200 \mathrm{~m} / \mathrm{z}$ that are consistent with hydrated states of the hydronium ion and that also appear in control measurements of aqueous solutions with no amino acid present. Tryptophan, which has a lower solubility than the other amino acids studied, produced a relatively weak signal. Four proteinogenic amino acids are absent from this data: Aspartic acid and glutamic acid would only be measurable in negative ion mode because of their low isoelectric points; isoleucine is indistinguishable from leucine based on $m / z$, so it was not studied; and tyrosine gave poor emission characteristics, likely related to its low solubility in water.

Figure 2c shows mass spectra of glutathione and two chemically modified variants, s-nitrosoglutathione, and s-acetylglutathione. Glutathione is a biologically important tripeptide [18], and the variants we studied result from common post-translational modifications. Nanocapillaries with $20 \mathrm{~nm}$ inner 
bioRxiv preprint doi: https://doi.org/10.1101/2021.08.15.456243; this version posted August 15,2021 . The copyright holder for this preprint (which was not certified by peer review) is the author/funder. All rights reserved. No reuse allowed without permission.

diameter tips generated the peptide ions from $100 \mathrm{mM}$ aqueous solutions with a $\mathrm{pH}$ between 3.1 and 3.9, adjusted by the addition of acetic acid. The glutathione spectrum shows a single peak at $307 \mathrm{~m} / \mathrm{z}$, which corresponds to the singly charged, unsolvated glutathione ion. The spectra of s-acetylglutathione and s-nitrosoglutathione show dominant peaks at $349 \mathrm{~m} / \mathrm{z}$ and $336 \mathrm{~m} / \mathrm{z}$, respectively, corresponding to the singly charged, unsolvated peptide ions; each spectrum also shows two progressively smaller peaks 18 and $36 \mathrm{~m} / z$ to the right of the dominant peak, corresponding to singly and doubly solvated peptide ions, respectively.

Two lines of evidence lead us to rule out the conventional, droplet-mediated electrospray mechanism (Fig. 1a) as the main source of ions that we measure. First, our instrument lacks the background gas that normally sustains the evaporation of solvent from droplets in an electrospray [9]. In high vacuum, nanoscale aqueous droplets shed only a small fraction of their mass before the evaporation process freezes up due to latent heat loss [19]. Therefore, a sustained release of ions from droplets cannot occur in our instrument. Second, the small size of a nanocapillary chokes off the fluid flow rate to the point that it cannot support a droplet-producing cone-jet. Figure 3a shows the measured relationship between the inner diameter of a tip and the flow rate of water through it with an applied pressure difference of 1 atm [13]. Also shown is the minimum stable flow rate predicted for a cone-jet of an aqueous solution similar to ours (see supplemental material) $[14,20,21]$. The flow rate in nanocapillaries with tip diameters smaller than $100 \mathrm{~nm}$ is at least 3 orders of magnitude lower than that minimum value.

We can explain our findings with an alternative ion emission mechanism: the evaporation of ions directly from the liquid surface at the nanopore, as 
bioRxiv preprint doi: https://doi.org/10.1101/2021.08.15.456243; this version posted August 15,2021 . The copyright holder for this preprint (which was not certified by peer review) is the author/funder. All rights reserved. No reuse allowed without permission.

illustrated in Fig. 1b. Ion evaporation is a thermal process by which ions escape from a liquid with assistance from a strong electric field at the surface [16]. A strong enough electric field typically arises when the ratio of the conductivity, $K$, to the flow rate, $Q$, of an electrified liquid is sufficiently large [22, 23]. Accordingly, previous studies have observed ion evaporation from highly conductive liquids such as liquid metals [24], ionic liquids [25], and concentrated electrolyte solutions in formamide [26]. The amino acid solutions we measured have relatively low conductivities (in the range $0.01-0.5 \mathrm{~S} / \mathrm{m}$ ), but the flow rate in a nanocapillary is exceptionally low $(<10 \mathrm{pL} / \mathrm{min})[13]$, so the resulting $K / Q$ is as large as the value achieved by the ionic liquid $\mathrm{EMI}^{-\mathrm{BF}_{4}}$ while exhibiting ion evaporation with no droplet emission [25]. Furthermore, the distributions of ion solvation states we measured in Fig. 1d and elsewhere are similar to the distributions measured by Luedtke et al. from sodium iodide in formamide, which they also attributed to ion evaporation [27].

It is striking that we mostly measured bare ions, rather than solvated ion clusters in Fig. 2b and c. We can rule out collisions with gas molecules as a mechanism for desolvating ion clusters after they leave the source. The kinetic theory of gases gives the probability of collisions between an ion and another molecule (see Supplemental Information). The most likely molecules for an ion to encounter at $10^{-7}$ torr are the water molecules that also evaporate from the meniscus of the ion source. Figure $3 \mathrm{~b}$ shows the cumulative probability of a $1.4 \mathrm{~nm}$ diameter ion cluster (the approximate size of an amino acid ion with a full water solvation shell) colliding with a gas molecule as it travels away from the meniscus. The collision probability saturates near $\sim 2 \%$ over a path length of $1 \mathrm{~m}$, which exceeds the size of our instrument. Thus we surmise that the unsolvated ions we measured left the ion source in that bare state. 
bioRxiv preprint doi: https://doi.org/10.1101/2021.08.15.456243; this version posted August 15,2021 . The copyright holder for this preprint (which was not certified by peer review) is the author/funder. All rights reserved. No reuse allowed without permission.

In summary, we have demonstrated a nanopore ion source that emits amino acid and small peptide ions directly into high vacuum. The ability to emit bare ions, as opposed to solvated ion clusters, facilitates the identification of different amino acids and post-translational modifications. Ions evidently evaporate directly from the liquid meniscus at the tip, which removes the need for a background gas to free ions from droplets. By doing away with background gas collisions and transfer capillaries, the nanopore ion source removes the primary modes of ion loss and shuffling during transfer into conventional mass spectrometers.

We envision the marriage of nanopores with mass spectrometry leading to a single-molecule protein sequencing technology. The basic idea, illustrated in Fig. 3c, is to drive a denatured protein through a nanopore ion source small enough that the amino acids must pass through in sequence. Sequencing would involve fragmenting the protein into its constituent amino acids as they transit the tip, and then identifying each one by determining its $m / z$ in the mass spectrometer. The sequential ordering of monomers could be preserved by fragmenting the protein sufficiently close to the tip [10]. A magnetic sector mass analyzer combined with an array of single ion detectors can be used to monitor all the relevant mass channels simultaneously. It will be necessary to denature proteins near the nanopore tip, which may be accomplished with chemical denaturants such as urea [28], high temperatures [29], or interactions with the nanopore surface [30]. It may be possible to fragment the denatured proteins using UV photodissociation $[31,32]$ or a protein digestion complex such as ClpXP [33]. 
bioRxiv preprint doi: https://doi.org/10.1101/2021.08.15.456243; this version posted August

15,2021 . The copyright holder for this preprint (which was not certified by peer review) is the author/funder. All rights reserved. No reuse allowed without permission.

\section{References}

[1] Restrepo-Pérez, L., Joo, C. \& Dekker, C. Paving the way to singlemolecule protein sequencing. Nature Nanotechnology 13 (9), 786-796 (2018). URL https://doi.org/10.1038/s41565-018-0236-6. https://doi. org/10.1038/s41565-018-0236-6 .

[2] Swaminathan, J. et al. Highly parallel single-molecule identification of proteins in zeptomole-scale mixtures. Nature biotechnology 36 (11), 1076$1082(2018)$.

[3] Ouldali, H. et al. Electrical recognition of the twenty proteinogenic amino acids using an aerolysin nanopore. Nature Biotechnology 38 (2), 176-181 (2020) .

[4] Brinkerhoff, H., Kang, A. C., Liu, J., Aksimentiev, A. \& Dekker, C. Infinite re-reading of single proteins at single-amino-acid resolution using nanopore sequencing. bioRxiv (2021) .

[5] Zhao, Y. et al. Single-molecule spectroscopy of amino acids and peptides by recognition tunnelling. Nature nanotechnology 9 (6), 466 (2014) .

[6] Aebersold, R. \& Mann, M. Mass-spectrometric exploration of proteome structure and function. Nature 537 (7620), 347-355 (2016) .

[7] Cole, R. B. Electrospray and MALDI mass spectrometry: fundamentals, instrumentation, practicalities, and biological applications (John Wiley \& Sons, 2011).

[8] Taylor, G. I. Electrically driven jets. Proceedings of the Royal Society of London. A. Mathematical and Physical Sciences 313 (1515), 453-475 
bioRxiv preprint doi: https://doi.org/10.1101/2021.08.15.456243; this version posted August

15,2021 . The copyright holder for this preprint (which was not certified by peer review) is the author/funder. All rights reserved. No reuse allowed without permission.

(1969) .

[9] Kebarle, P. \& Verkerk, U. H. Electrospray: from ions in solution to ions in the gas phase, what we know now. Mass spectrometry reviews 28 (6), 898-917 (2009) .

[10] Maulbetsch, W., Wiener, B., Poole, W., Bush, J. \& Stein, D. Preserving the sequence of a biopolymer's monomers as they enter an electrospray mass spectrometer. Physical Review Applied 6 (5), 054006 (2016) .

[11] Smith, R. D., Loo, J. A., Edmonds, C. G., Barinaga, C. J. \& Udseth, H. R. New developments in biochemical mass spectrometry: electrospray ionization. Analytical chemistry 62 (9), 882-899 (1990) .

[12] Hawkridge, A. M. Practical considerations and current limitations in quantitative mass spectrometry-based proteomics (2014) .

[13] Maulbetsch, W. Nanopore Mass Spectrometry. Ph.D. thesis, Brown University (2018). URL https://repository.library.brown.edu/studio/item/ bdr:792908/.

[14] Higuera, F. Qualitative analysis of the minimum flow rate of a cone-jet of a very polar liquid. Journal of Fluid Mechanics 816, 428-441 (2017) .

[15] Higuera, F. Model of the meniscus of an ionic-liquid ion source. Physical Review E 77 (2), 026308 (2008).

[16] Iribarne, J. V. \& Thomson, B. A. On the evaporation of small ions from charged droplets. The Journal of Chemical Physics 64 (6), 2287-2294 (1976). URL https://aip.scitation.org/doi/abs/10.1063/1.432536. https: //doi.org/10.1063/1.432536, https://arxiv.org/abs/https://aip.scitation. 
bioRxiv preprint doi: https://doi.org/10.1101/2021.08.15.456243; this version posted August

15,2021 . The copyright holder for this preprint (which was not certified by peer review) is the author/funder. All rights reserved. No reuse allowed without permission.

org/doi/pdf/10.1063/1.432536 .

[17] Bush, J. et al. The nanopore mass spectrometer. Review of Scientific Instruments $8 \mathbf{8}$ (11), 113307 (2017) .

[18] Meister, A. \& Anderson, M. E. Glutathione. Annual review of biochemistry $\mathbf{5 2}$ (1), 711-760 (1983) .

[19] Caleman, C. \& van der Spoel, D. Temperature and structural changes of water clusters in vacuum due to evaporation. The Journal of chemical physics 125 (15), 154508 (2006) .

[20] Ganan-Calvo, A. M. Cone-jet analytical extension of taylor's electrostatic solution and the asymptotic universal scaling laws in electrospraying. Physical review letters 79 (2), 217 (1997) .

[21] De La Mora, J. F. \& Loscertales, I. G. The current emitted by highly conducting taylor cones. Journal of Fluid Mechanics 260, 155-184 (1994)

[22] Guerrero, I., Bocanegra, R., Higuera, F. \& De La Mora, J. F. Ion evaporation from taylor cones of propylene carbonate mixed with ionic liquids. Journal of Fluid Mechanics 591, 437-459 (2007) .

[23] Romero-Sanz, I., Bocanegra, R., Fernandez De La Mora, J. \& GameroCastano, M. Source of heavy molecular ions based on taylor cones of ionic liquids operating in the pure ion evaporation regime. Journal of Applied Physics 94 (5), 3599-3605 (2003) . 
bioRxiv preprint doi: https://doi.org/10.1101/2021.08.15.456243; this version posted August

15,2021 . The copyright holder for this preprint (which was not certified by peer review) is the author/funder. All rights reserved. No reuse allowed without permission.

[24] Prewett, P. D., Mair, G. L. R. \& Thompson, S. P. Some comments on the mechanism of emission from liquid metal ion sources. Journal of Physics D: Applied Physics 15 (7), 1339-1348 (1982). URL https://doi.org/10.1088\%2F0022-3727\%2F15\%2F7\%2F027. https://doi. org/10.1088/0022-3727/15/7/027 .

[25] Romero-Sanz, I., Bocanegra, R., Fernandez de la Mora, J. \& GameroCastaño, M. Source of heavy molecular ions based on taylor cones of ionic liquids operating in the pure ion evaporation regime. Journal of Applied Physics 94 (5), 3599-3605 (2003). URL https://doi.org/10. 1063/1.1598281. https://doi.org/10.1063/1.1598281, https://arxiv.org/ abs/https://doi.org/10.1063/1.1598281 .

[26] Gamero-Castano, M. Electric-field-induced ion evaporation from dielectric liquid. Physical review letters 89 (14), 147602 (2002) .

[27] Luedtke, W. et al. Nanojets, electrospray, and ion field evaporation: Molecular dynamics simulations and laboratory experiments. The Journal of Physical Chemistry A 112 (40), 9628-9649 (2008) .

[28] Bennion, B. J. \& Daggett, V. The molecular basis for the chemical denaturation of proteins by urea. Proceedings of the National Academy of Sciences 100 (9), 5142-5147 (2003) .

[29] Bischof, J. C. \& He, X. Thermal stability of proteins. Annals of the New York Academy of Sciences 1066 (1), 12-33 (2006) .

[30] Mortensen, D. N. \& Williams, E. R. Surface-induced protein unfolding in submicron electrospray emitters. Analytical chemistry 88 (19), 9662-9668 (2016) . 
bioRxiv preprint doi: https://doi.org/10.1101/2021.08.15.456243; this version posted August

15,2021 . The copyright holder for this preprint (which was not certified by peer review) is the author/funder. All rights reserved. No reuse allowed without permission.

[31] Brodbelt, J. S. Photodissociation mass spectrometry: new tools for characterization of biological molecules. Chemical Society Reviews 43 (8), $2757-2783(2014)$.

[32] Nikogosyan, D. N. \& Gorner, H. Laser-induced photodecomposition of amino acids and peptides: extrapolation to corneal collagen. IEEE Journal of selected topics in quantum electronics 5 (4), 1107-1115 (1999)

[33] Baker, T. A. \& Sauer, R. T. Clpxp, an atp-powered unfolding and proteindegradation machine. Biochimica et Biophysica Acta (BBA)-Molecular Cell Research 1823 (1), 15-28 (2012).

\section{Acknowledgements}

We would like to thank Oxford Nanopore Technologies ltd. for their support of this work. Aspects of this work were also supported by the Institute for Molecular and Nanoscale Innovation at Brown University. N.D. was partially supported by the Brown IMSD program (NIH R25GM083270). H.S. was partially supported by the Brown UTRA program. B.W. was partially supported by NSF 1409577 . 
bioRxiv preprint doi: https://doi.org/10.1101/2021.08.15.456243; this version posted August 15,2021 . The copyright holder for this preprint (which was not certified by peer review) is the author/funder. All rights reserved. No reuse allowed without permission.

\section{Methods}

\section{Preparing nanocapillaries}

Nanocapillaries were pulled from $7.5 \mathrm{~cm}$ long quartz capillaries with $0.7 \mathrm{~mm}$ inner diameter and $1 \mathrm{~mm}$ outer diamter (QF100-70-7.5 from Sutter Instruments). A laser puller (P-2000, Sutter Instruments) pulled nanocapillaries with sub-100 $\mathrm{nm}$ tips according to the following single-line recipe: heat $=650$, velocity $=45$, delay $=175$, pull $=190$. The nanocapillaries were coated with $5 \mathrm{~nm}$ of carbon and imaged by scanning electron microscopy (LEO 1530 VP, Zeiss) to measure the tip size. The nanocapillaries were plasma cleaned in air using a plasma preen (Plasmatic Systems Inc.) for two minutes prior to being filled with analyte solution.

\section{Amino acid solutions}

Amino acid solutions were prepared by dissolving the amino acid of interest (Sigma-aldrich) in DI water (Millipore) at concentrations of $100 \mathrm{mM}$, with the exception of tryptophan which was prepared at a concentration of $50 \mathrm{mM}$. Between 0.1-0.5\% v/v glacial acetic acid (Sigma-Aldrich) was added to the amino acid solutions to reduce the $\mathrm{pH}$ below the amino acid's isoelectric point. Glutathione, s-acetylglutathione, and s-nitrosoglutathione solutions were prepared by dissolving the peptides in DI water at concentrations of $100 \mathrm{mM}$. The glutathione and s-acetylglutathione were purchased in powder form (Sigma-aldrich), and the S-nitrosoglutathione was lab synthesized from glutathione according to a protocol from T.W. Hart [?]. The pH and conductivities of each solution were measured using a $\mathrm{pH}$ meter (Ultrabasic Benchtop, 
bioRxiv preprint doi: https://doi.org/10.1101/2021.08.15.456243; this version posted August 15,2021 . The copyright holder for this preprint (which was not certified by peer review) is the author/funder. All rights reserved. No reuse allowed without permission.

Denver Instruments) and conductivity meter (Sension+ EC71 GLP, Hach) respectively.

\section{Delivering solutions to the ion source}

Sample solutions are delivered to the nanocapillary tip and flushed away by a tube-in-tube system. A thin inner PEEK tube (150 $\mu \mathrm{m}$ i.d., $360 \mu \mathrm{m}$ o.d.)(IDEX Health and Science) carries sample solution in while a wider PEEK tube (0.04 i.d., 1/16" o.d.)(IDEX Health and Science) carries used solution away from the tip around the outside of the inner tube. A syringe pump (NE-300, New Era Pump Systems) is used to supply fresh solution to the ion source view the inner tube. A VacuTight upchurch fitting (IDEX Health and Science) is used to create a seal around the base of the nanocapillary and end of the outer tube to prevent the solution from leaking into the vacuum. The tube-in-tube system is housed in a 1/4" diameter steel tube which enters the vacuum chamber of the mass spectrometer through a KF-40 to Quick-Connect adapter (Lesker Vacuum).

\section{Mass spectrometer}

The mass spectrometer used for all measurements presented in this work is a custom-built quadrupole mass spectrometer fully described by Bush et al. The instrument comprises a custom einzel lens, a quadrupole mass filter (MAX500, Extrel), an ion bender (Extrel) and a channel electron multiplier detector with a conversion dynode (DeTech 413), which is sensitive to single ions. The base pressure of the instrument is $10^{-8}$ torr, and the pressure measured while a 
bioRxiv preprint doi: https://doi.org/10.1101/2021.08.15.456243; this version posted August 15,2021 . The copyright holder for this preprint (which was not certified by peer review) is the author/funder. All rights reserved. No reuse allowed without permission.

nanocapillary filled with aqueous solution is installed in the mass spectrometer is typically $10^{-7}-10^{-6}$ torr.

\section{Amino acid and glutathione measurements}

Nanocapillaries were prefilled with the amino acid or peptide solution using a microfil flexible needle (World Precision Instruments). The filled nanocapillaries were then mounted on the tube-in-tube system, and inserted into the mass spectrometer. The solution at the tip was continuously refreshed by pumping solution through the inner tubing from a syringe pump (NE-300, New Era Pump Systems) at a rate of $0.4 \mathrm{~mL} /$ hour. A voltage of $+100 \mathrm{~V}$ was applied to the electrode inside the capillary using a high voltage source-meter (2657A, Keithley Instruments) while a negative voltage was slowly applied to the extraction electrode using a high voltage power supply (Burle) until ionization was observed. The onset of ionization typically occurred when the total extraction voltage was between 200 and $350 \mathrm{~V}$. 
bioRxiv preprint doi: https://doi.org/10.1101/2021.08.15.456243; this version posted August 15,2021 . The copyright holder for this preprint (which was not certified by peer review) is the author/funder. All rights reserved. No reuse allowed without permission.
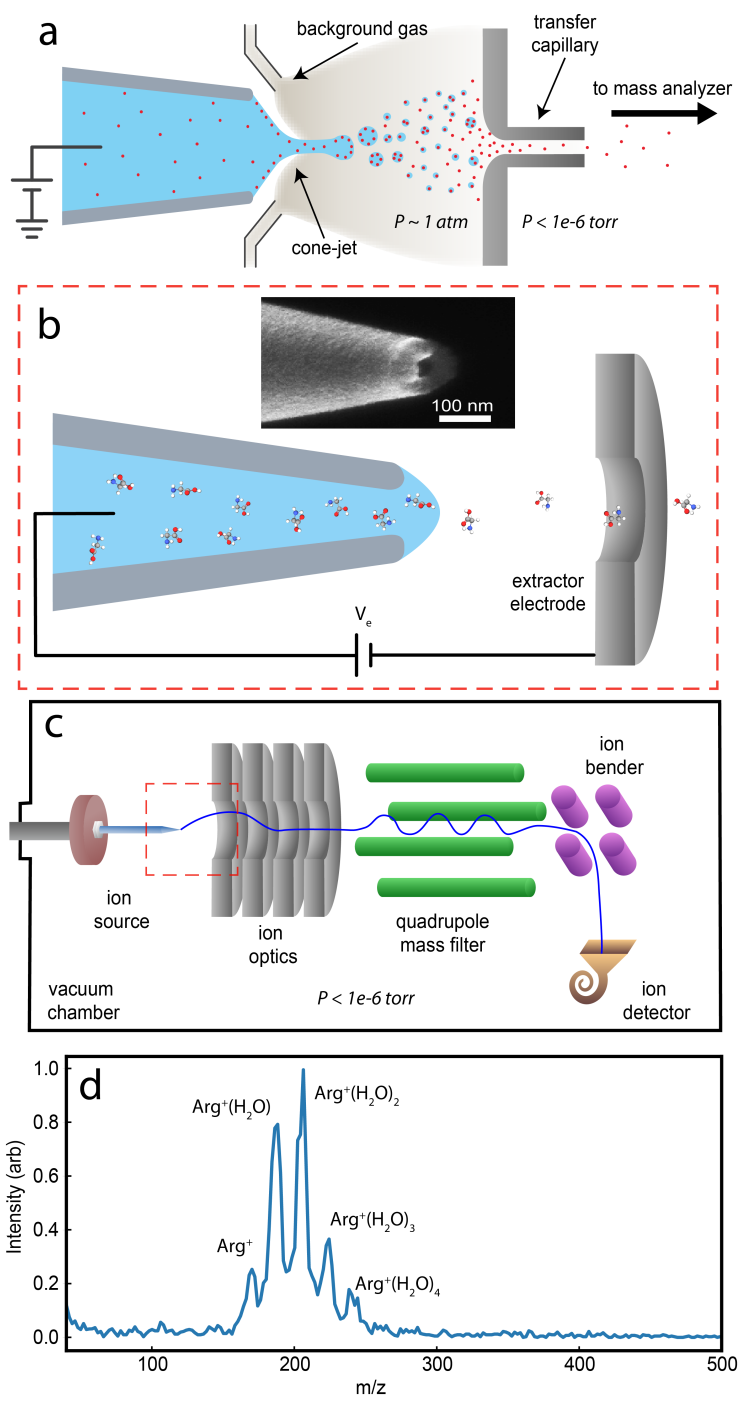

Fig. 1 a, Schematic of conventional electrospray ionization highlighting the background gas that stimulates evaporation of solvent from droplets and the transfer capillary where significant ion loss occurs. b. Schematic of a nanopore ion source showing the liquid-filled nanocapillary tip, the extractor electrode, and the extraction voltage $V_{e}$ applied between them. Inset shows an SEM image of the tip of a pulled quartz nanocapillary with a tip inner diameter of $30 \mathrm{~nm}$. c, Schematic of the mass spectrometer used in this study. Ion optics comprising an extractor electrode and an einzel lens extract ions from the liquid meniscus at the ion source and focus them through a quadrupole mass filter and an electrostatic ion bender. The transmitted ions strike a channel electron multiplier detector which is sensitive to single ions. d, Mass spectrum of $100 \mathrm{mM}$ arginine in aqueous solution obtained with a $41 \mathrm{~nm}$ inner diameter nanopore ion source in our quadrupole mass spectrometer. 
bioRxiv preprint doi: https://doi.org/10.1101/2021.08.15.456243; this version posted August 15,2021 . The copyright holder for this preprint (which was not certified by peer review) is the author/funder. All rights reserved. No reuse allowed without permission.

a

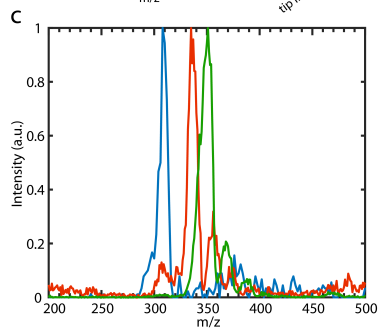

b

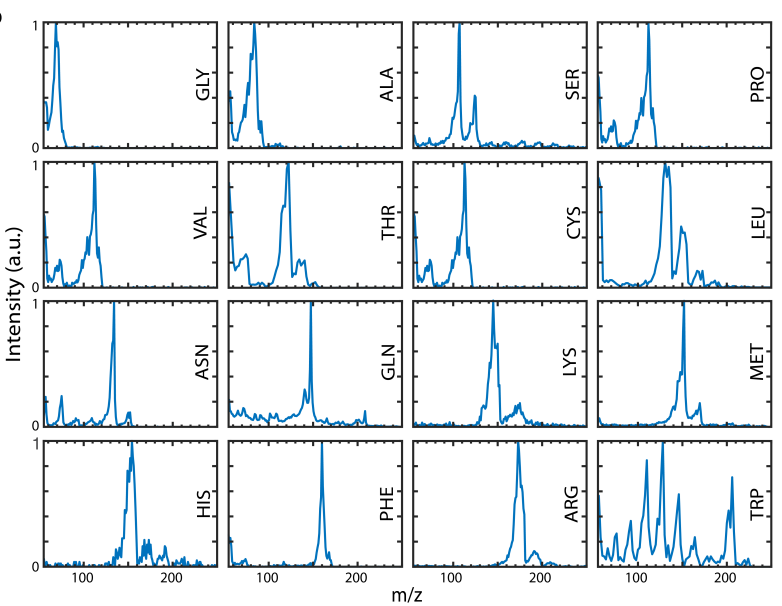

Fig. 2 a, Mass spectrum of $100 \mathrm{mM}$ arginine solution in $\mathrm{H}_{2} \mathrm{O}$ using nanopore ion sources with 3 different inner tip diameters. b, Gallery of 16 amino acid mass spectra, ordered from top left to bottom right by mass. All experiments were carried out using nanocapillaries with 20-60 nm inner tip diameters. c, Overlaid mass spectra of glutathione (blue) and two of it's PTM variants, s-nitrosoglutathione (green) and s-acetylglutathione (red). 
bioRxiv preprint doi: https://doi.org/10.1101/2021.08.15.456243; this version posted August 15,2021 . The copyright holder for this preprint (which was not certified by peer review) is the author/funder. All rights reserved. No reuse allowed without permission.

a

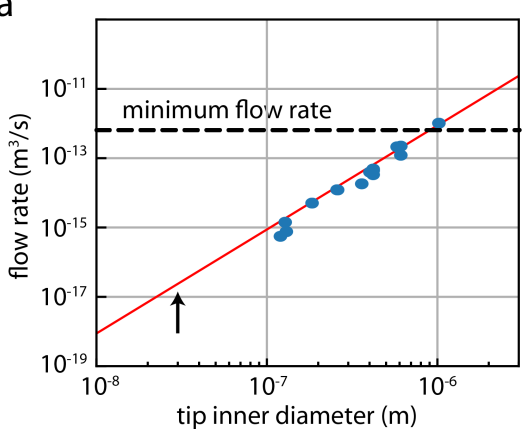

b

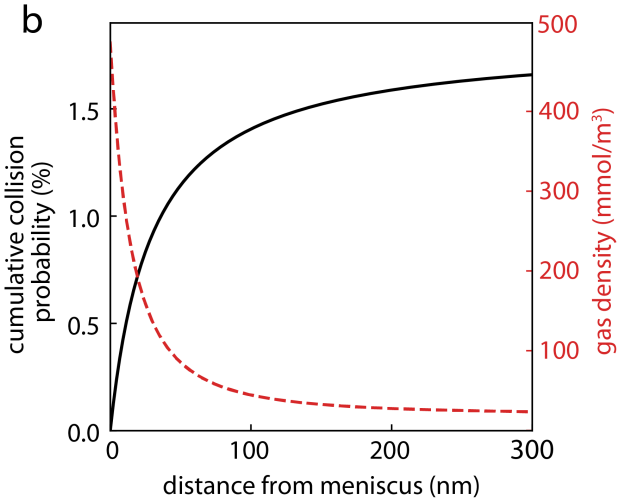

$\mathrm{C}$

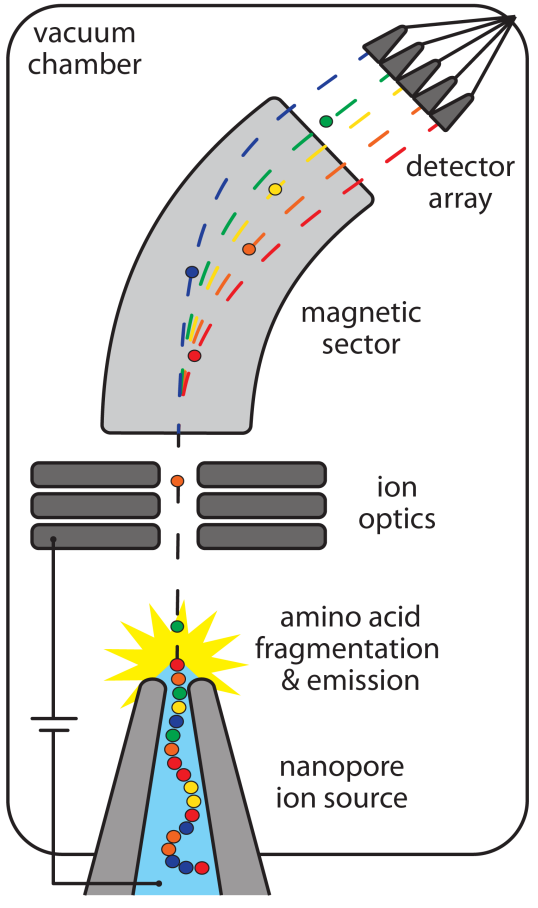

Fig. 3 a, Dependence of the flow rate through a nanocapillary on the inner tip diameter. The blue dots show data collected from 14 nanocapillaries ranging in inner diameter from $120 \mathrm{~nm}$ to $1 \mu \mathrm{m}$ obtained by our group [13]. The solid red line is a fit to the data to a model of Poiseuille flow through a truncated cone. Dashed line is $5 \times 10^{-13} \mathrm{~m}^{3} \mathrm{~s}^{-1}$, the theoretical minimum flow rate for a stable cone-jet in aqueous solutions with conductivity $0.1 \mathrm{~S} / \mathrm{m}$ [14]. The black arrow points to the approximate flow rate predicted for a nanocapillary with tip inner diameter of $30 \mathrm{~nm}$. b. Calculation of the cumulative probability that an emitted amino acid with a small hydration shell (radius $=7 \AA$ ) will collide with an evaporated water molecule or background gas molecule as a function of distance from the meniscus. The dashed line shows the calculated maximum possible water vapor density as a function of the distance from the meniscus. We conservatively assumed that the vapor pressure on the vacuum side of the meniscus is 8.75 torr, half the equilibrium vapor pressure of water at room temperature. c, Schematic of an envisioned mass spectrometer capable of single molecule protein sequencing. 